УДК 621.318.38:631.53.027.3

(C) 2014

\author{
Ходурський В. Є., кандидат технічних наук, \\ Ківа О. В., стариий викладач, \\ Китаєв $\boldsymbol{G}$. В., студент
}

Полтавський національний технічний університет ім. Юрія Кондратюка

\title{
РОЗРОБКА СПОСОБУ НАНЕСЕННЯ ЕМІТЕРА НА ЕЛЕКТРОДИ ГАЗОРОЗРЯДНИХ ЛАМП ШЛЯХОМ ВАКУУМУВАННЯ
}

\section{Рецензент- доктор технічних наук, професор В. О. Бондар}

Була проведена розробка способу нанесення емітера на електроди газорозрядних ламп шляхом занурення їх у суспензію емітера з попереднім вакуумуванням. Проведені експериментальні дослідження на електродах ламп ДРЛ-250 із вивчення впливу попереднього вакуумування на приріст маси емітера, нанесеного на електрод, і на ступінь заповнення внутрішніх порожнин електрода емітером, на основі яких запропонована технологія нанесення емітера на електроди газорозрядних ламп із попереднім вакуумуванням.

Подаються результати проведених експериментальних випробувань та одержані порівняльні характеристики для способів нанесення емітера на електроди газорозрядних ламп за відомою технологією та шляхом вакуумування.

Ключові слова: газорозрядні лампи, емітер, електрод, суспензія, вакуумування.

Постановка проблеми. Одним із основних факторів, що визначають термін служби газорозрядних ламп, $є$ якість нанесення емітера на їх електроди, яка залежить, у свою чергу, від рівномірності нанесення шару емітера та наповненості внутрішніх порожнин електрода емітером [1].

Аналіз останніх досліджень i публікацій, у яких започатковано розв'язання проблеми. Відомий спосіб нанесення емітера полягає у тому, що емітер суспензують у рідині, після чого занурюють у цю суспензію електроди, витримують у ній, а далі випаровують розчинник [4].

Цей спосіб, на жаль, не забезпечує якісного заповнення порожнин, утворених витками спіралі та керном.

Частково ця проблема розв'язана нагріванням електродів перед зануренням їх у суспензію [3], проте нагрівання електродів може спричинити їх неконтрольоване окиснення в повітрі.

Мета - дослідити спосіб нанесення емітера на електроди газорозрядних ламп шляхом вакуумування для збільшення маси емітера на електродах та підвищення терміну їх роботи.
Завдання дослідження. На думку авторів, у разі завантаження електродів у герметичну посудину, відкачуванні 3 неї повітря та подальшому заповненні іiі суспензією емітера до атмосферного тиску вакуум, створений у порожнинах електродів, сприятиме нагнітанню суспензії у порожнини під дією зовнішнього тиску.

Методи дослідження. В якості емітера використали суспензію порошків цирконату барію та окису ітрію у воді. Випробування проводилися на електродах ртутних дугових ламп високого тиску ДРЛ-250, які являють собою центральний стрижень - керн із вольфраму діаметром 1 мм, із накрученою на нього двошаровою спіраллю 3 вольфрамового дроту діаметром 0,4 мм, із числом витків у першому шарі $11 \pm 1$, у другому шарі $-8 \pm 1$.

Партію електродів помістили у скляну колбу, оснащену патрубком із вентилем. Колбу відкачали до тиску $\sim 1$ мм рт. ст. Занурили патрубок у суспензію й відкрили вентиль, аби суспензія заповнила колбу з електродами.

Витримавши електроди в суспензії 1 хв., іiі вилили, а електроди висушили в сушильній шафі.

Результати досліджень. Результати випробувань наведені у таблиці.

Для отримання порівняльних даних паралельно нанесли емітер на іншу партію електродів за відомою технологією [2]. В обох партіях (по 119 шт.) визначили масу електродів без емітера i 3 емітером одразу після сушіння.

Після зважування електроди 3 емітером, нанесеним за обома методами, помістили в пробірки й усю партію потрусили, потім висипали в плоскі кювети і продули стисненим повітрям для видалення емітера, що обсипався 3 електродів, i зважили кожну партію знову.

Із даних таблиці видно, що порівняно з відомим запропонований авторами спосіб дає змогу суттєво збільшити масу нанесеного на електрод емітера, що за інших рівних умов відповідно підвищить ресурс дугових ртутних ламп [5]. 
Порівняльні характеристики технологій нанесення емітера методом вакуумування та традиційним промисловим способом

\begin{tabular}{|c|c|c|c|}
\hline Середня маса електрода (мг) & $\begin{array}{c}\text { Відомий } \\
\text { спосіб }\end{array}$ & $\begin{array}{c}\text { Спосіб } \\
\text { вакуумування }\end{array}$ & \multirow{4}{*}{$\begin{array}{c}\text { Приріст маси } \\
\text { емітера } \\
\text { у відсотках } \\
\text { відомим } \\
\text { методом }\end{array}$} \\
\hline До нанесення емітера & 440,8925 & 440,4808 & \\
\hline Після сушіння & 445,6975 & 445,9058 & \\
\hline Після очищення емітера, що обсипався & 442,1513 & 442,3367 & \\
\hline \multicolumn{3}{|c|}{ Середня маса емітера, нанесеного на електрод (мг) } & \\
\hline Після сушіння & 4,8050 & 5,4250 & $12,9 \%$ \\
\hline Після очищення емітера, який обсипався & 1,2588 & 1,8559 & $47,4 \%$ \\
\hline
\end{tabular}

Висновок. Запропонований спосіб забезпечує краще заповнення внутрішніх порожнин електрода, внаслідок чого збільшується маса нанесеного на електрод емітера та якість його 3'єднання з матеріалом електрода. Застосування запропонованого способу практично не збільшує

\section{БІБЛІОГРАФІЯ}

1. Герус В. Л. Физические основы электроннолучевых приборов. - М. : Наука, 1993. - 228 с.

2. Денисов В. П. Производство электрических источников света . - М. : Наука, 1975. - 488 с.

3. Ківа О. В., Стасюк Т. О., Ходурський В. $С$. Розробка способу нанесення емітера на електроди газорозрядних ламп із попереднім нагріванням // Вісник Полтавської державної аграрної трудоємкості процесу й не потребує складного обладнання [2], у зв'язку з чим він може бути реалізованим без суттєвих затрат в існуючому технологічному процесі виготовлення електродів газорозрядних ламп.

академії, №3, 2012. - С. 146-148.

4. Патент UA№7903, МПК 7Н01J9/02. Спосіб нанесення емітера на електроди газорозрядних ламп / Ходурський В. Є., Фернебок О. - Бюл. ДДІВ України. - 2005, №7.

5. Рохлин Г. Н. Разрядные источники света. М. : Энергоатомиздат, 1991. - 416 с. 